\author{
Marcin Pigłowski \\ Akademia Morska w Gdyni \\ Wydział Przedsiębiorczości i Towaroznawstwa \\ e-mail: m.piglowski@wpit.am.gdynia.pl
}

\title{
Food dangerous for the consumer in INFOSAN events
}

\author{
Codes JEL: C38, F53, L66, Q18
}

Keywords: FAO, WHO, food safety, cluster analysis

Summary. The goal of the study was to analyze the dependences between food type and year, involvement type and hazard type (adopted as variables) within events of INFOSAN (International Food Safety Authorities Network). The study covered 209 events included in the annual reports for 2011-2015. Cluster analysis and scatterplots were used. Most frequently the following food types were notified: meat and meat products (in 2014), fish and other seafood (2015) and also vegetables and vegetable products, nuts and oilseeds, fruit and fruit products (2011) and milk and dairy products (2012 and 2013). In these products there were usually stated biological hazards and the INFOSAN was directly and significantly involved in events (within coordination). The similar types of dangerous food products notified in the INFOSAN and the European RASFF (Rapid Alert System for Food and Feed) and American RFR (Reportable Food Registry) can point out the possibility of closer cooperation within these systems. The international food flow requires the appropriate conditions in supply chain. Therefore, the attention of consumers should be paid to food from national, regional and local markets.

\section{Introduction}

The international trade of food brings many benefits but also risk to consumers (spreading of foodborne pathogens and contaminants across national borders). The Food and Agriculture Organization of the United Nations (FAO) and the 
World Health Organization (WHO) always well recognized the need to build links among food safety authorities internationally (WHO, FAO, 2013).

Therefore in 2004 the International Food Safety Authorities Network (INFOSAN) was launched (FAO, WHO, 2016) and in 2012 the INFOSAN Community Website started (WHO, FAO, 2013). The INFOSAN is the early warning system/network, through which member states can report food-borne diseases in real-time (Kleter, Marvin, 2009; Marvin, Kleter, Prandini, Dekkers, Bolton, 2009; Marvin, Kleter, Frewer, Cope, Wentholt, Rowe, 2009; Soon, Singh, Baines, 2011). Tirado et al. (2010) stated that the INFOSAN strategy is emergency preparedness and response.

The INFOSAN has nowadays 186 members states (with Emergency Contact Point and Focal Point), which respond to requests for information and take the initiative within sharing and disseminating food safety information (particularly notified as food safety events) of potential international relevance (FAO and WHO, 2016). So, the INFOSAN ensures the rapid sharing of information about food safety events that are international in scope (Fisher, 2011; Stein and Ellis, Jones, 2011; Tlustos, Anderson, Evans, 2013).

Therefore, the goal of the study was to analyze the dependences between food type and year, involvement type and hazard type (adopted as variables) within events of INFOSAN.

\section{Data and methods}

The data for the period considered (2011-2015) originated from appendices of three INFOSAN annual reports. In subsequent years there were noted: 46 events in 2011, 42 in 2012 (WHO, FAO, 2013), 44 in 2013 (WHO, FAO, 2014), 40 in 2014 and 37 in 2015 (FAO, WHO, 2016), in total 209 events.

Four following variables were adopted: food type, year, involvement type and hazard type. The other variables couldn't be adopted, because in the case of:

- region(s) involved, country(ies) involved there was a possibility of occurring more than one value in one event,

- specific hazard values depended on value of variable hazard type and were to varied,

- specific food values depended on value of variable food type and were to varied,

- length values were to varied.

In order to increase the readability of figures some (long) names of food types were shortened, i.e.: „cereals...” (instead of cereals and cereal-based products), „fats and oils..." (fats and oils of animal and vegetable origin), „foods for infants..." (foods for infants and small children), „herbs, spices..." (herbs, spices and condiments), „special products” (products for special nutritional use), „snack, desserts...” (snack, desserts and other foods) and ,vegeta- 
bles..." (vegetables and vegetable products). In the case of variable involvement type used shortened value coordination (instead of co-ordination used for 2011 and 2012) and shortened value verification (instead of verification request used for 2011, 2012, 2014 and 2015).

The data were collected in Excel and then transferred to Statistica 12. Subsequently, cluster analysis was performed by joining (tree clustering) with following settings: linkage rule: complete linkage, distance measure: 1-r Pearson. The dependences between food type and other variables were examined using (bubble) scatterplots and also pivot tables.

\section{Results and discussion}

In figure 1 there is presented a tree diagram. The first cluster contained three variables (food type, year and hazard type) and the second cluster was oneelement cluster including only involvement type variable. The variables: year and hazard type were linked directly, which means that for many events occurred the same values of mentioned variables. However, the variable involvement type was a separate cluster, which is a result of large variation of values within this variable.

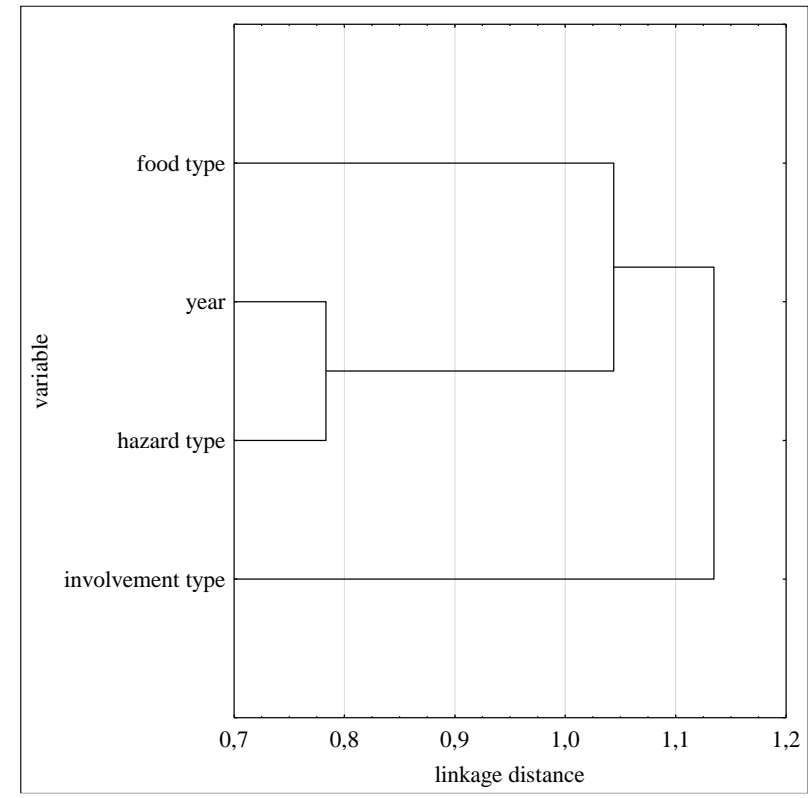

Figure 1. Tree diagram

Source: own study.

In subsequent figures there are presented dependences between food type and year (fig. 2), involvement type (fig. 3) and hazard type (fig. 4). In these 
scatterplots, however, the dependences were presented only in an approximate way. Therefore, the more accurate results were read from the pivot tables taking into account number of events above the mean.

Thus, considering the year (number of events above the mean) the following food types were notified: composite food (in 2011), fish and other seafood (2012-2015), fruit and fruit products (2011, 2012 and 2015), meat and meat products (2011-2015), milk and dairy products (2012 and 2013), nuts and oilseeds (2011 and 2013), unknown (2015) and vegetables and vegetable products (2011 and 2013) (see also figure 2).

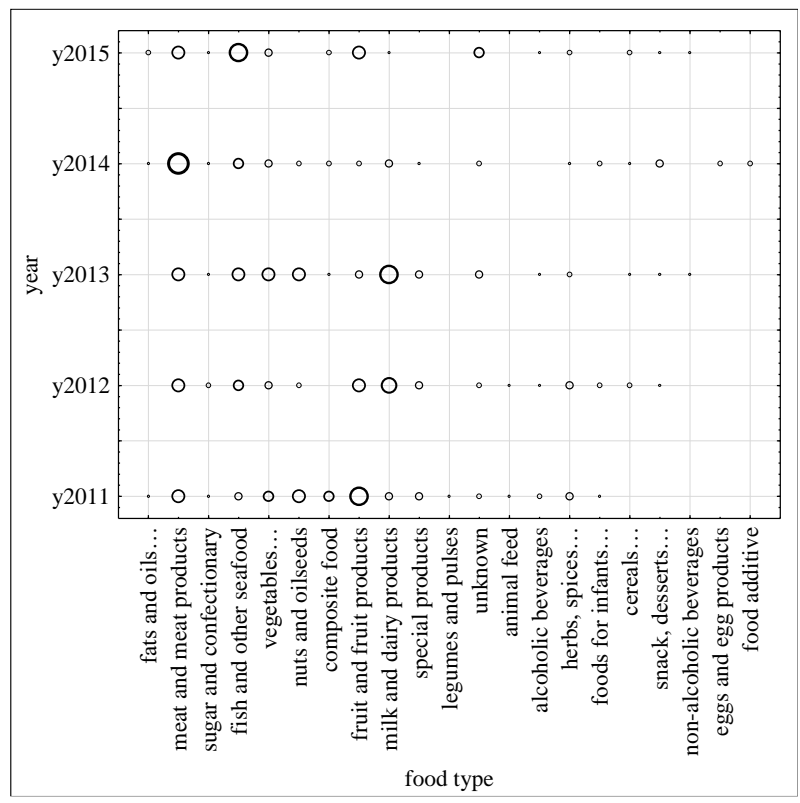

Figure 2. Dependence of food type and year

Source: own study.

The most commonly used involvement type was coordination and then verification (fig. 3). In the case of coordination the INFOSAN Secretariat actively obtained and disseminated information from INFOSAN members within food safety events of international concern. This also may have resulted in an INFOSAN alert/notice being posted on the INFOSAN Community Website. However, the verification was used when IFOSAN Secretariat obtained information about food safety event of potential international concern and requested additional details from INFOSAN Emergency Contact Point (FAO, WHO, 2016). The number of events above the mean value occurred in the case of the following food types: cereals and cereal-based products (coordination), composite food (coordination), fish and other seafood (coordination), fruit and fruit products (coordination), herbs, spices and condiments (coordination), meat and meat products (coordination and 
verification), milk and dairy products (coordination and verification), snack, desserts and other foods (coordination), special products (coordination), unknown (coordination) and vegetables and vegetable products (coordination and verification).

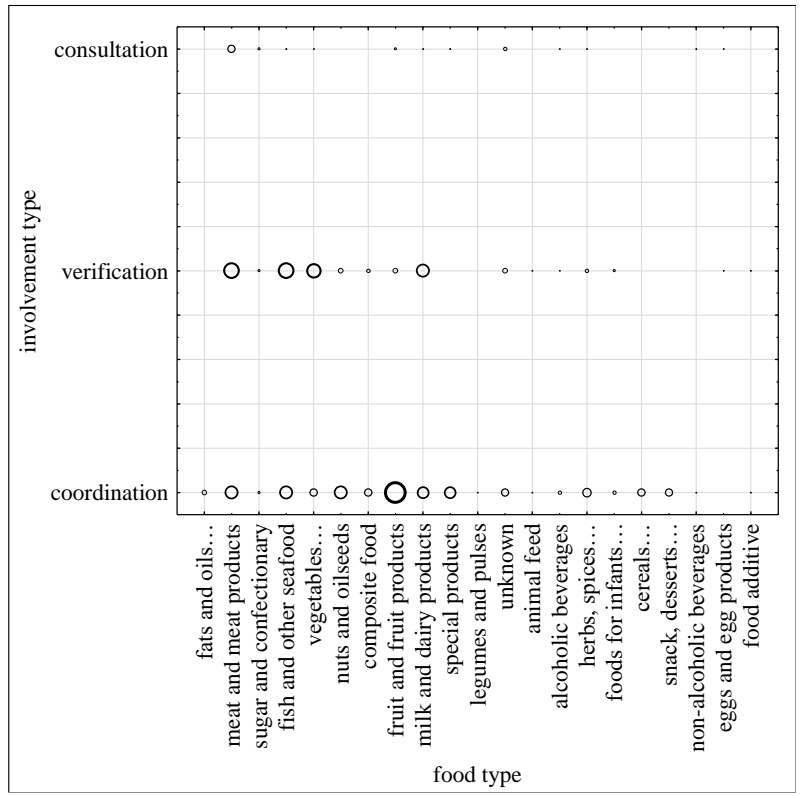

Figure 3. Dependence of food type and involvement type

Source: own study.

The most frequently biological hazards were notified and much less chemical ones (fig. 4). The events (number above the mean) related to: fish and other seafood (biological and chemical), fruit and fruit products (biological), herbs, species and condiments (biological), meat and meat products (biological), milk and dairy products (biological and chemical), nuts and oilseeds (biological), special products (chemical), unknown (biological) and vegetables and vegetable products (biological). 


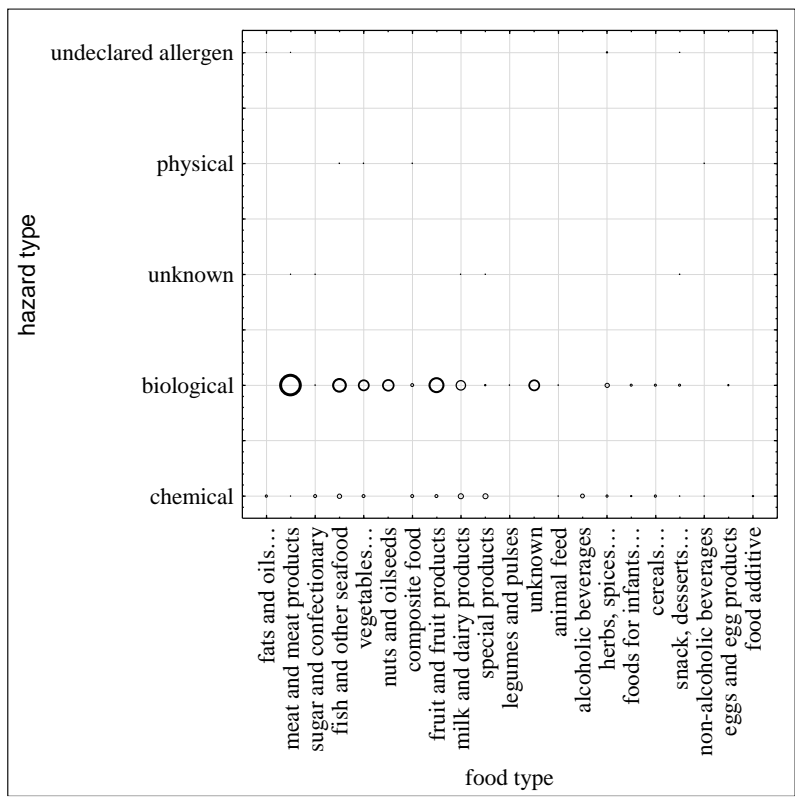

Figure 4. Dependence of food type and hazard type

Source: own study.

Reports and documents related to the INFOSAN informed mainly about biological hazards, i.e.: Salmonella infections (Cortiñas Abrahantes, Bollaerts, Aerts, Ogunsanya, Van der Stede, 2009), Salmonella transmission trough contaminated food and water (Liu et al., 2011), Escherichia coli in spinach (Marvin, Kleter, Prandini, Dekkers, Bolton, 2009), Escherichia coli in spinach, norovirus in oysters, Salmonella in chocolate (Kleter, Marvin, 2009) and avian influenza in poultry products from India (Tauxe, Doyle, Kuchenmüller, Schlundt, Stein, 2010). However, there were also information about chemical hazards, i.e.: melamine in egg powders from China (Ding et al., 2012), dioxins and dioxins-like PCBs in breast milk (Polder et al., 2008) and bisphenol A (Fischnaller, Bakry, Bonn, 2016; Huang et al., 2012).

\section{Conclusions}

The number of INFOSAN events slightly decreased in the last years: 46 events in 2011, 42 in 2012, 44 in 2013, 40 in 2014 and 37 in 2015. However, in 2014 meat and meat products were notified particularly often and in 2015 fish and other seafood. There were also the other food types notified, i.e.: vegetables and vegetables products, nuts and oilseeds, fruit and fruit products (in 2011) and milk and dairy products (in 2012 and 2013). In these products biological haz- 
ards usually stated and they were considered within coordination as the involvement type (direct and significant participation of the INFOSAN).

The similar products were also notified within European RASFF (Rapid Alert System for Food and Feed) and American RFR (Reportable Food Registry). These systems operate on large and stable food markets. It points to the possibility of closer cooperation between the FAO and WHO (within the INFOSAN) on the one hand and the European Union and the United Stated on the other hand in the field of information exchange and prevention of food safety hazards.

The international food flow requires to ensure the appropriate conditions (temperature, humidity, tightness of packaging) in supply chain in order to limit or eliminate the microbiological hazards. The attention of consumers should be also to a greater extent paid to food from national, regional and local markets, because shortening the food chain would reduce the possibility of such hazards.

\section{Bibliography}

Cortiñas Abrahantes, J., Bollaerts, K., Aerts, M., Ogunsanya, V., Van der Stede, Y. (2009). Salmonella serosurveillance: Different statistical methods to categorise pig herds based on serological data. Preventive Veterinary Medicine, 89 (1-2), 59-66. DOI: 10.1016/j.prevet med.2009.01.009.

Ding, X., Bai, S., Zhang, K., Wang, L., Wu, C., Chen, D., Jia, G., Bai, J. (2012). Tissue Deposition and Residue Depletion in Broiler Exposed to Melamine-Contaminated Diets. Journal of Integrative Agriculture, 11 (1), 109-115.

FAO, WHO (2016). INFOSAN activity report 2014/2015. Geneva: FAO, WHO.

Fischnaller, M., Bakry, R., Bonn, G.K. (2016). A simple method for the enrichment of bisphenols using boron nitride. Food Chemistry, 194, 49-155. DOI: 10.1016/j.foodchem.2015.07.117.

Fisher, I.S.T. (2011). Surveillance for foodborne pathogens in humans. In: S. Brul, P.M. Fratamico, T.A. McMeekin (eds), Tracing Pathogens in the Food Chain (p. 11-29). Cambridge: Woodhead Publishing.

Huang, Y.Q., Wong, C.K.C., Zheng, J.S., Bouwman, H., Barra, R., Wahlström, B., Neretin, L., Wong, M.H. (2012). Bisphenol A (BPA) in China: A review of sources, environmental levels, and potential human health impacts. Environment International, 42, 91-99. DOI: 10.1016/j.envint.2011.04.010.

Kleter, G.A., Marvin, H.J.P. (2009). Indicators of emerging hazards and risks to food safety. Food and Chemical Toxicology, 47 (5), 1022-1039. DOI: 10.1016/j.fct.2008.07.028.

Liu, B., Zhang, L., Zhu X., Shi, Ch., Chen, J., Liu, W., He, X., Shi, X. (2011). PCR identification of Salmonella serogroups based on specific targets obtained by comparative genomics. International Journal of Food Microbiology, 144 (3), 511-518. DOI: 10.1016/j.ijfoodmicro. 2010.11.010.

Marvin, H.J.P., Kleter, G.A., Frewer, L.J., Cope, S., Wentholt, M.T.A., Rowe, G. (2009). A working procedure for identifying emerging food safety issues at an early stage: Implications for European and international risk management practices. Food Control, 20 (4), 345-356. DOI: 10.1016/j.foodcont.2008.07.024.

Marvin, H.J.P., Kleter, G.A., Prandini, A., Dekkers, S., Bolton, D.J. (2009). Early identification systems for emerging foodborne hazards. Food and Chemical Toxicology, 47 (5), 915-926. DOI: $10.1016 /$ j.fct.2007.12.021. 
Polder, A., Gabrielsen, G.W., Odland, J.Ø., Savinova, T.N., Tkachev, A., Løken, K.B., Skaare, J.U. (2008). Spatial and temporal changes of chlorinated pesticides, PCBs, dioxins (PCDDs/PCDFs) and brominated flame retardants in human breast milk from Northern Russia. Science of The Total Environment, 391 (1), 41-54. DOI: 10.1016/j.scitotenv.2007. 10.045 .

Soon, J.M., Singh, H., Baines, R. (2011). Foodborne diseases in Malaysia: A review. Food Control, 22 (6), 823-830. DOI: 10.1016/j.foodcont.2010.12.011.

Stein, C., Ellis, A., Jones, T. (2011). Detection, investigation and control of outbreaks of foodborne disease. In: S. Brul, P.M. Fratamico, T.A. McMeekin (eds), Tracing Pathogens in the Food Chain (p. 47-88). Cambridge: Woodhead Publishing.

Tauxe, R.V., Doyle, M.P., Kuchenmüller, T., Schlundt, J., Stein, C.E. (2010). Evolving public health approaches to the global challenge of foodborne infections. International Journal of Food Microbiology, 139, S16-S28. DOI: 10.1016/j.ijfoodmicro.2009.10.014.

Tirado, M.C., Clarke, R., Jaykus, L.A., McQuatters-Gollop, A., Frank, J.M. (2010). Climate change and food safety: A review. Food Research International, 43 (7), 1745-1765. DOI: 10.1016/j.foodres.2010.07.003.

Tlustos, C., Anderson, W., Evans, R. (2013). Responding to food contamination incidents: principles and examples from cases involving dioxins. In: M. Rose, A. Fernandes (eds), Persistent Organic Pollutants and Toxic Metals in Foods (p. 110128). Cambridge: Woodhead Publishing.

WHO, FAO (2013). INFOSAN activity report 2011-2012. Geneva: WHO, FAO.

WHO, FAO (2014). INFOSAN activity report 2013. Geneva: WHO, FAO.

\section{Żywność niebezpieczna dla konsumenta w zdarzeniach sieci INFOSAN}

Slowa kluczowe: FAO, WHO, bezpieczeństwo żywności, analiza skupień

Streszczenie. Celem badań była analiza zależności między typem żywności a rokiem, typem zaangażowania i typem zagrożenia (przyjętych jako zmienne) w ramach zdarzeń sieci INFOSAN (Międzynarodowej Sieci Organów ds. Bezpieczeństwa Żywności). Badania objęły 209 zdarzeń zawartych w raportach rocznych z lat 2011-2015. Najczęściej zgłaszane były następujące typy żywności: mięso i produkty mięsne (w 2014 roku), ryby i inna żywność pochodzenia morskiego (2015), a także warzywa i produkty z warzyw, orzechy i nasiona oleiste, owoce i produkty z owoców (2011) oraz mleko i produkty mleczarskie (2012 i 2013). W produktach tych najczęściej zgłaszano zagrożenia biologiczne, a sieć INFOSAN była bezpośrednio i znacząco zaangażowana $\mathrm{w}$ koordynację działań związanych z danym zdarzeniem. Podobne typy niebezpiecznych produktów żywnościowych zgłaszane $\mathrm{w}$ ramach sieci INFOSAN oraz europejskiego RASFF (Systemu Wczesnego Ostrzegania o Niebezpiecznej Żywności i Paszach) i amerykańskiego RFR (Rejestru Zgłoszonej Żywności) mogą spowodować możliwość bliższej współpracy w ramach tych systemów. Międzynarodowy przepływ żywności wymaga odpowiednich warunków w łańcuchu żywnościowych. Uwaga konsumentów powinna być zatem zwrócona na żywność z rynków krajowych, regionalnych i lokalnych.

\section{Cytowanie}

Pigłowski, M. (2017). Food dangerous for the consumer in INFOSAN events. Marketing $i \mathrm{Za}$ rzadzanie, 2 (48), 189-196. DOI: 10.18276/miz.2017.48-17. 